\title{
Adaptation of Released Tomato Varieties (Solanum lycopersicum L. mill) Under Jimma Condition South West Ethiopia
}

\author{
Getachew Etana Gemechu ${ }^{1}$ Neim Seman ${ }^{2} \quad$ Tewodros Mulualem Beyene ${ }^{3}$ \\ Jimma Agricultural Research Center, EIAR
}

\begin{abstract}
An experiment was conducted for two consecutive years since 2014 to 2016 in Jimma area, south west with ten improved tomato varieties and on farmer's local in randomized complete block design with three replications. Among the varieties tested, there was a high significant variation $(\mathrm{P}<0.05)$ in mean number of fruit cluster per plant, mean marketable fruit number per plant and mean marketable fruit yield ton per hectare in each year and mean of two years evaluation. Since 2014/15, Variety Eshete scored highest significance difference among varities with the score of 7.5 in mean number of fruit cluster per plant. Mean of marketable fruit number per plant in variety Bishola, Metadel and Melkasalsa scored highest significance difference among all tested varities with the score of $14,13.25$ and 13 respectively. Mean of marketable fruit yield in ton per hectare was highly significant difference in variety Melkasalsa (33.01 ton $\mathrm{ha}^{-1}$ ) and followed by Miya (28.25 ton ha ${ }^{-1}$ ). Since 2015/16, the variety Melkasalsa resulted in highest significance difference in its mean number of fruit cluster per plant among all tested varities with the score of 23.33 which was three fold of its first year. Mean of marketable fruit number per plant was resulted in highest significance difference in variety Melkasalsa (54) which was four fold of its first year (13). Mean of marketable fruit yield in ton ha $^{-1}$ was highly significant difference in variety Melkasalsa (40.547 ton ha${ }^{1}$ ) and about $22.83 \%$ yield advantage than the former year. The least marketable fruit yield ton ha ${ }^{-1}$ was recorded by the variety Bishola $\left(6.6\right.$ ton $\left.\mathrm{ha}^{-1}\right)$ and Metadel $\left(8.66\right.$ ton ha $\left.{ }^{-1}\right)$. Mean of marketable fruit yield in ton ha ${ }^{-1}$ over two years was highly significant difference in variety Melkasalsa (36.78 ton ha $\left.{ }^{-1}\right)$. As a result Melkasalsa was recommended for Jimma area and to be expanded through demonstrations.
\end{abstract}

Keywords: fruit number, fruit cluster, fruit yield, improved variety.

DOI: $10.7176 /$ JNSR/9-20-04

Publication date:October $31^{\text {st }} 2019$

\section{Introduction}

Tomato (Lycopersicon esculentum Mill.) is one of the most widely grown vegetable crops in the world. It is a seasonal climbing plant of the family solanaceae which is grown as an annual and produced for its fruits. The crop has been grown between 700 and 2200 meter above sea level having 700 to over $1400 \mathrm{~mm}$ annual rain fall in different seasons, under different weather conditions at different levels of technology (Birhanu and Ketema, 2010). The plant requires a warm and dry climate. The optimum mean day temperature for growth of tomato lies between $21^{\circ} \mathrm{C}$ and $26^{\circ} \mathrm{C}$ and temperature above $32^{\circ} \mathrm{C}$ during fruit development inhibit the formation of red color. It prefers loamy sand to silty loam soils having good drainage is important with Optimum $\mathrm{pH}$ range is from 5.5 to 7.0(Birhanu and Ketema, 2010).

Tomato is the $3^{\text {rd }}$ largest vegetable crop after potato and sweet potato and as a processing crop it ranks first among all vegetables (Agrisnet, 2010). Originally, it came from tropical area of Mexico, then to Peru (Maerere et al., 2006; FAO, 2005). It spread throughout the world following the Spanish colonization of the Americas (Wikipedia, 2016). It is one of the most popular and important edible nutritious vegetable crops for fresh consumption as well as for processing in the world. It is widely cultivated in tropical, subtropical and temperate climates (FAO, 2006).

The leading tomato producing country is China. She is the biggest tomato producer in the world with annual production of 34.1 million tons (FAOSTAT, 2010). Next to china, United State of America, India, Egypt, Turkey, Iran, Mexico, Brazil and Indonesia are the leaders (FAO, 2006).

It is used as canned vegetable having multiple uses and supplies essential nutrients in human diets (Choudhury, 1979). It is popularly used for both commercial and home use purposes. The fresh produce is sliced and used as salad. The processed products like tomato paste, tomato juice, and tomato catch-up are also widely usable. It is used in preparing soups, sauces, stews, salads and other dishes, and used in large quantities as compared to other vegetables. It is used for healing wounds because of antibiotic properties found in ripe fruits and has good source of Vitamins like A, B and C (Baloch, 1994).

In Ethiopia, there is no exact information when tomato was first introduced; however, the crop is cultivated in different major growing areas of the country. The climatic and soil conditions of Ethiopia allows the cultivation of tomato which is largely in the eastern and central parts of the mid-to low-land areas of the country (Birhanu and Ketema, 2010). Whole and peel-tomato are produced in our country which is recognized as quality product for both local and export markets. As a result of this, it provides a route out of poverty for small scale producers who live in Ethiopia as well as in developing countries (Tewodros and Asfaw, 2013). 
Ethiopia is the world's $84^{\text {th }}$ largest producer of tomato (CSA, 2012; CSA, 2015). In Ethiopia, tomato ranks fourth in total production (5.45\%) after Ethiopian cabbage, red pepper and green pepper from cultivated vegetable crops. It also takes a third rank in area coverage (4.49\%) next to red pepper and Ethiopian cabbage from cultivated vegetable crops. Large scale production of tomato takes place in the upper awash valley under irrigated and rainfed conditions whereas small scale production for fresh market is a common practice around Koka, Ziway, WondoGenet, Guder, Bako and many other areas (Lemma, 2002). The crop has high economic importance in Ethiopia. It is consumed in every household in different styles, but in certain areas, such as Walo, Hararge, Shawa, Jimma and Wallaga, it is also an important co-staple food (Ambecha et al., 2012).

In Ethiopia from 2014/15 to 2015/16 production of two years, area of production increased from 5,011.62 hectare to $9,524.42$ hectare which was $90.05 \%$ change in area of production. From these areas, there was change in production from $30,699.950$ ton to $59,156.336$ ton which was $92.69 \%$ change in production. In the same year, yield harvested per hectare was 6.126 ton to 6.211 ton per hectare which was least/no change $1.39 \%$ (CSA, 2016). Even though several tomato varieties had been released nationally and recommended by the Melkassa Agricultural Research Center for commercial production and small scale farming systems in Ethiopia, its national mean yield is 6.2 ton $\mathrm{ha}^{-1}$ (CSA, 2016; Regassa et al., 2016). This is by far below the world average 34.84 ton ha ${ }^{-1}$ which is due to poor management practice in Ethiopia (Lemma, 2002). In addition to this, in jimma area, only few varieties were tested only for a season. This leads to variable and low yield below national average yields which is also due to limited access of improved commercial tomato varieties, adaptation and poor production management. Hence to fill this gaps, this experiment was conducted with objective of:

$\checkmark$ To evaluate the adaptation of released tomato varieties in Jimma area, south west;

$\checkmark$ To select the most high yielder and most preferred varities by producers in Jimma area, south west;

$\checkmark \quad$ To generate and compile information for producers and different users of the crops.

\section{Materials and Methods}

Description of study area

The experiment was conducted at Jimma Agricultural Research Center which is located $366 \mathrm{~km}$ South West of Finfine (Addis Ababa). It is geographically located at latitude $7^{\circ} 46^{\prime} \mathrm{N}$ and longitude $36^{\circ} 47^{\circ} \mathrm{E}$ having an altitude of 1750 meter above sea level. The soil of the study area is Nitisol which is the dominant with a pH of 5.3(Beyene, 2013). The area receives an average annuals rainfall of $1622.43 \mathrm{~mm}$ and average maximum and minimum temperatures of $24.2^{\circ} \mathrm{C}$ and $11.9^{\circ} \mathrm{C}$ respectively and average maximum relative humidity of $67.43 \%$ (JARC AMG,2018).

The $1^{\text {st }}$ season experiment was established since November, 2014 to march,2015.Throughout these season the highest rain fall was observed in December with $59 \mathrm{~mm}$ and the least was observed in January with $8.30 \mathrm{~mm}$ (Fig 1).The highest minimum temperature was observed in February $25.66^{\circ} \mathrm{c}$ and the least was observed in December with $10.47^{\circ} \mathrm{c}$ (Fig 1). The highest maximum monthly temperature was observed January with $26.16^{\circ} \mathrm{c}$ and the least was observed in month of February with $11.64^{\circ} \mathrm{c}$ (Fig 1). The highest relative humidity was observed in the month of December with $79.16 \%$ and the least is in the month of March with $67.48 \%$ (Fig 1). Throughout these five months of cropping season, $223.70 \mathrm{~mm}$ of total and $44.6 \mathrm{~mm}$ average monthly rain fall was recorded(Fig 3); average maximum monthly temperature of $\left(22.83^{\circ} \mathrm{c}\right)$, average minimum monthly temperature of $\left(13.86^{\circ} \mathrm{c}\right)$ and average monthly RH of $73.87 \%$ was recorded(Fig 3 ). The Livelihood of the people is basically crop farming and animal rearing.

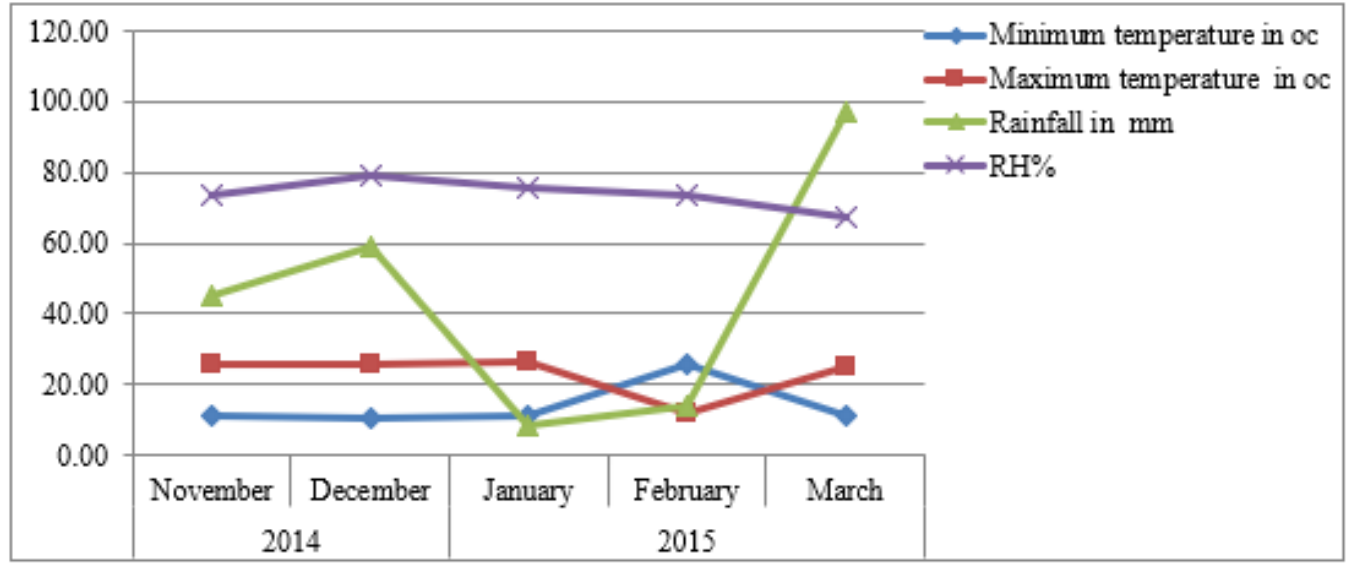

Fig 1. Distribution of monthly rain fall $(\mathrm{mm})$, maximum temperature $\left({ }^{\circ} \mathrm{c}\right)$, minimum temperature $\left({ }^{\circ} \mathrm{c}\right)$ and $\mathrm{RH}(\%)$ though out cropping season of $1^{\text {st }}$ year experiment since November, 2014 to March, 2015.

Source: (JARC AMG, 2018) 
The $2^{\text {nd }}$ season experiment was established since November, 2015 to march,2016.Throughout these season the highest rain fall was observed in November $(84.6 \mathrm{~mm})$ and the least was observed in January $(34.7 \mathrm{~mm})($ Fig 2).The highest minimum temperature was observed in March $\left(11.02^{\circ} \mathrm{c}\right)$ and the least was observed in November $\left(9.48^{\circ} \mathrm{c}\right)$ (Fig 2). The highest maximum monthly temperature was observed February $\left(27.5^{\circ} \mathrm{c}\right)$ and the least was observed in month of March $\left(13.65^{\circ} \mathrm{c}\right)$ (Fig 2). The highest relative humidity was observed in the month of December ( 74.9\%) and the least is in the month of February (42.48\%) (Fig 2). Throughout these five months of $2^{\text {nd }}$ year cropping season, $336.50 \mathrm{~mm}$ of total and $67.3 \mathrm{~mm}$ average monthly rain fall was recorded(Fig 3); average maximum monthly temperature of $\left(23.97^{\circ} \mathrm{c}\right)$, average monthly minimum temperature of $\left(10.12^{\circ} \mathrm{c}\right)$ and average monthly RH of $65.92 \%$ was recorded (Fig 3).

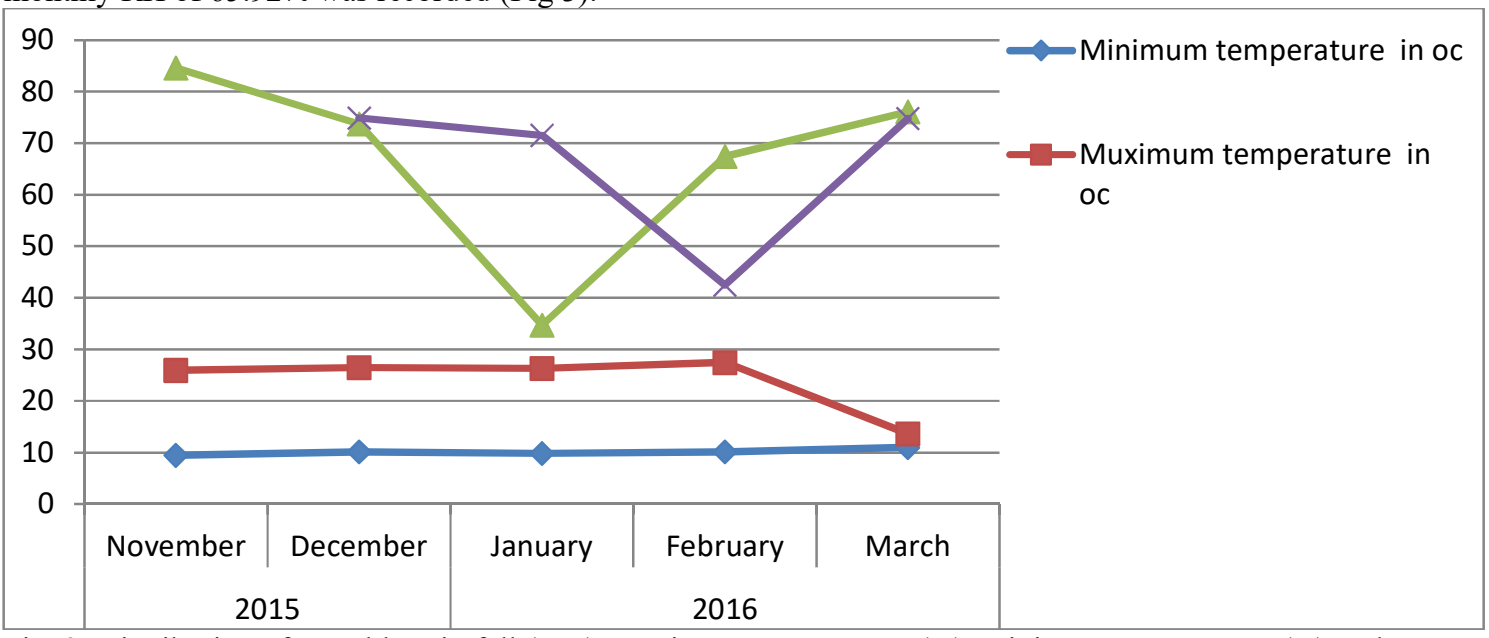

Fig 2. Distribution of monthly rain fall $(\mathrm{mm})$, maximum temperature $\left({ }^{\circ} \mathrm{c}\right)$, minimum temperature $\left({ }^{\circ} \mathrm{c}\right)$ and $\mathrm{RH}(\%)$ though out cropping season of $2^{\text {nd }}$ year experiment since November, 2015 to March, 2016.

Source: (JARC AMG, 2018)

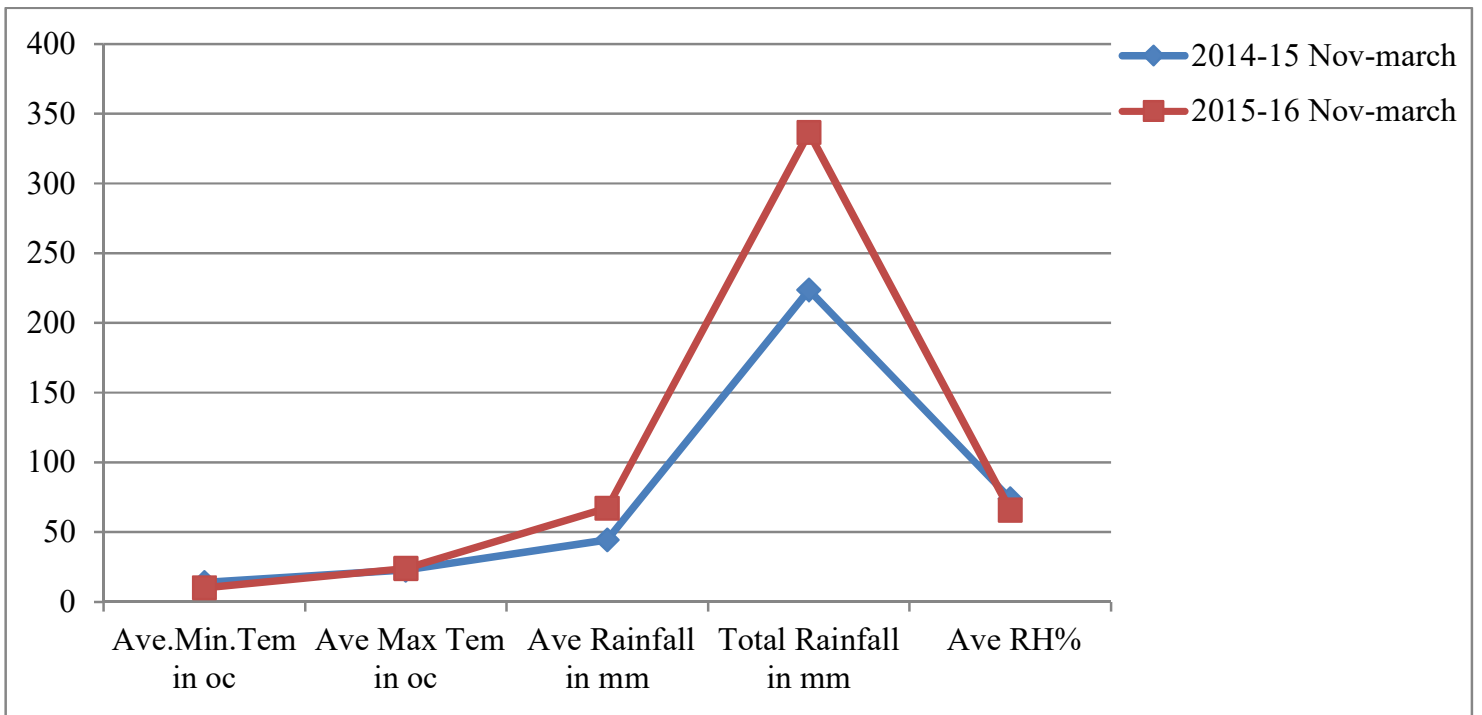

Fig 3. Distribution of Total rain fall $(\mathrm{mm})$, average rain fall $(\mathrm{mm})$, average maximum temperature $\left({ }^{\circ} \mathrm{c}\right)$, average minimum temperature $\left({ }^{\circ} \mathrm{c}\right)$ and average monthly $\mathrm{RH}(\%)$ though out Cropping Season of $1^{\text {st }}$ and $2^{\text {nd }}$ year experiment since November,2014 to March, 2015 and November, 2015 to March, 2016 respectively.

Source: (JARC AMG, 2018)

\section{Experimental material}

Nine tomato varieties were used in the experiment, five of which are determinate type (Bishola, Chali, Cochoro, Fetan, Eshete and Melkasalsa) while another four are semi-determinate type (Metadel, Miya, Melkashola and Arp tomato d2) and one local variety. The seeds of all the varieties were obtained from the germplasm collections 
maintained at Melkassa Agricultural Research Center (MARC). The description of these varieties were presented in Table 1 below

Table 1.Planting materials

\begin{tabular}{|c|c|c|c|c|c|c|}
\hline Varieties & Altitude & Growth habit & Unique character & Utilization & $\begin{array}{l}\text { Maturity } \\
\text { days }\end{array}$ & $\begin{array}{l}\text { Research } \\
\text { Yield } \\
(\mathrm{Q} / \mathrm{ha})\end{array}$ \\
\hline Fetan & $\begin{array}{l}700- \\
2000\end{array}$ & Determinate & $\begin{array}{l}\text { Early maturing and concen } \\
\text { trated fruit yield }\end{array}$ & Fresh & $78-80$ & 454 \\
\hline Bishola & $\begin{array}{l}700- \\
2000\end{array}$ & Determinate & $\begin{array}{l}\text { Large fruit size, Green shoul } \\
\text { der fruit color before mature }\end{array}$ & Fresh & $85-90$ & 340 \\
\hline $\begin{array}{l}\text { Arp tomato } \\
\text { d2 }\end{array}$ & $\begin{array}{l}700- \\
2000\end{array}$ & $\begin{array}{l}\text { Semi- } \\
\text { determinate }\end{array}$ & $\begin{array}{l}\text { Large fruit size, Green shoul } \\
\text { der fruit color before mature }\end{array}$ & Fresh & $75-80$ & 394 \\
\hline Eshete & $\begin{array}{l}700- \\
2000\end{array}$ & $\begin{array}{l}\text { Semi- } \\
\text { determinate }\end{array}$ & $\begin{array}{l}\text { Medium fruit size, Slightly } \\
\text { flatten fruit shape }\end{array}$ & Fresh & $75-80$ & \\
\hline Metadel & $\begin{array}{l}700- \\
2000\end{array}$ & $\begin{array}{l}\text { Semi- } \\
\text { determinate }\end{array}$ & $\begin{array}{l}\text { Medium fruit size, Slightly } \\
\text { flatten fruit shape }\end{array}$ & Fresh & $75-80$ & 345 \\
\hline Cochoro & $\begin{array}{l}700- \\
2000\end{array}$ & $\begin{array}{l}\text { Semi- } \\
\text { determinate }\end{array}$ & $\begin{array}{l}\text { Round fruit shape, Green shou } \\
\text { lder fruit color before mature }\end{array}$ & processing & $75-90$ & 350 \\
\hline Melkashola & $\begin{array}{l}700- \\
2000\end{array}$ & Determinate & Globular fruit shape & Processing & $100-120$ & 430 \\
\hline Chali & $\begin{array}{l}700- \\
2000\end{array}$ & Determinate & Round fruit shape & Processing & $110-120$ & 300 \\
\hline Miya & $\begin{array}{l}700- \\
2000\end{array}$ & $\begin{array}{l}\text { Semi- } \\
\text { determinate }\end{array}$ & $\begin{array}{l}\text { High leaf coverage,Hard skin } \\
\text { fruit and Plum fruit shape }\end{array}$ & Fresh & $75-80$ & 471 \\
\hline Melkasalsa & $\begin{array}{l}700- \\
2000\end{array}$ & Determinant & $\begin{array}{l}\text { Small fruit size, Slightly } \\
\text { cylindrical fruit shape }\end{array}$ & Processing & $100-110$ & 320 \\
\hline Local & $700-200$ & $\begin{array}{l}\text { Semi- } \\
\text { determinate }\end{array}$ & Globular fruit shape & Fresh & $95-100$ & 400 \\
\hline
\end{tabular}

\section{Experimental Design and procedures.}

The experimental field or plots were laid out in randomized complete block design (RCBD) with three replications. The seedlings were carefully transplanted after 6 weeks to the experimental plots $(2.1 \times 3 \mathrm{~m}$ dimensions area $)$ which were designed to accommodate 44 plants per plot on four rows with the spacing of $70 \mathrm{~cm}$ between rows and $30 \mathrm{~cm}$ between plants (Lemma, 2002). The spacing between each plot and adjacent blocks was $0.5 \mathrm{~m}$ and $1 \mathrm{~m}$ respectively.

The field experiment was conducted during dry condition with supplemental irrigation (December, 2013 to March, 2014). The experimental plots on which the seedling raised were prepared and managed for prevention of fungal disease by applications of chemicals at JARC horticultural site. About 10 gram of seeds for each treatments were sown on the well prepared raised seed bed of $1.3 \mathrm{~m} \times 1.3 \mathrm{~m}$ size and raised $5 \mathrm{~cm}$ from the soil surface to provide good drainage for the removal of surplus cane watering. The seeds were sown in rows spaced $15 \mathrm{~cm}$ apart and covered lightly with fine soil before watering. The beds were watered every day until the seeds germinated fully and twice a week afterwards. Seedlings were thinned until an intra-row spacing of $3 \mathrm{~cm}$ was achieved.

All recommended agronomic practices like weeding, cultivation; irrigation, fertilizer applications taking and disease management were carried out uniformly during the growing season for all plots. Similarly, pre-plant granular Di-ammonium Phosphate at a rate of $200 \mathrm{~kg} \mathrm{ha}^{-1}$ and Urea fertilizer at rate $100 \mathrm{~kg} \mathrm{ha}^{-1}$ were applied (Lemma, 2002). Experimental plots were irrigated every day for the first two weeks to secure uniform establishment and then at weekly interval. Disease was managed by application of recommended fungicides Mancozeb750 DF at a rate of $2.5 \mathrm{~kg} \mathrm{ha}^{-1}(185 \mathrm{~kg} / 100 \mathrm{~L})$ in seven days intervals at seedling to transplanting date and 28 days interval at vegetative to pre-flowering stage.

Data collected and statistical analysis

Data were collected on parameters like Number of fruit cluster per plant, fruits number per plant , marketable fruit weight (gram) per plant and marketable fruit yield (tonha ${ }^{-1}$ ) (Lemma, 2002).

Number of fruit cluster per plant: the cluster of fruit on ten sample plant were counted and taken as average.

Marketable Fruit number per plant: The average number of marketable fruit per plant in successive harvest from ten sample plant.

Marketable Fruit weight per plant (kilogram): Calculated by dividing total marketable fruit weight per plot to total number of plants harvested per plot.

Marketable Fruit yield (ton ha ${ }^{-1}$ ): Sum of marketable fruit weight per plot (sample plant) from successive 
harvest $(\mathrm{kg})$ was taken and converted to ton per hectare.

Analysis of variance for the collected data parameters was performed using SAS computer software version 9.2 (SAS, 2009) and the treatment mean comparison was done by Least signifance difference (LSD) at 5\%. Pearson's correlations among all the collected parameters were also evaluated.

\section{Results and Discussions}

The result of the experiment in the $1^{\text {st }}$ revealed that, among the eleven varieties tested, there was a high significant variation between them $(\mathrm{P} \leq 0.05)$ in mean number of fruit cluster per plant, mean marketable fruit number per plant, fruit weight per plant and mean marketable fruit yield ton per hectare since 2014 to 2015 in Jimma area (Table 1). In mean number of fruit cluster per plant variety Eshete scored highest significance difference among all tested varities with the score of 7.5. But it was statistical parity with the variety Metadel and Local with score of 6.7 and 6.6 respectively. The least was recorded in the variety Melkashola (4.1). This variety was statistically par with variety Chali (4.8) and ARPTd2 tomato (4.5).

In mean of marketable fruit number per plant, variety Bishola, Metadel and Melkasalsa scored highest significance difference among all tested varities with the score of $14,13.25$ and 13 fruit number per plant respectively. But it was statistical parity with the variety Eshete with score of 12.83 mean marketable fruit number per plant. In consistency with this result, Yeshiwas et al.( 2016) reported that, variety Moneymaker gave the highest number of fruits per plant (46.4) than any other tomato varieties the same ecology to this experiment. The least was recorded in the variety ARPTd2 tomato (7.33) which was statistically par with variety Melkashola (7.9) and Chali (8.58).

Mean of marketable fruit weight per plant was highly significant difference in variety Melkasalsa $(0.69 \mathrm{~kg})$ and followed by Miya $(0.59 \mathrm{Kg})$. The least marketable fruit weight per plant was recorded by the variety Bishola $(0.12 \mathrm{Kg})$ and Bishola Eshete $(0.20 \mathrm{~kg})$. This indicated that, fruit weight is varying with variety which is directly linked to yield. An agreement to this, Fruit weight is one of the important traits that were directly linked with yield (Jindal et al., 2015).

Mean of marketable fruit yield in ton per hectare was highly significant difference in variety Melkasalsa (33.01 ton $\mathrm{ha}^{-1}$ ) and followed by Miya (28.25 ton ha $\mathrm{ha}^{-1}$ ). This highest marketable fruit was due to the integration of highest fruit number, fruit weight and number of fruit cluster recorded on the Melkasalsa variety. The genetic make-up of the variety also plays significant role on yield of these varieties. An agreement to this, Richardson (2013) reported that, variety 'Soraya' presenting the highest mean yields of marketable fruit yield.

The least marketable fruit weight per plant was recorded by the variety Bishola (5.87ton ha $\mathrm{h}^{-1}$ ) and Eshete (9.84ton ha $\mathrm{ha}^{-1}$ ). The yield varied between 5.87 ton ha ${ }^{-1}$ to 33.01 ton $\mathrm{ha}^{-1}$. Similarly, variations in total fruit yield per hectare ranged from 53 to 71 ton $\mathrm{ha}^{-1}$ were observed under open field growing conditions (Yeshiwas et al., 2016). Also a varied yield was reported by indicating the potential yields of tomato ranged from 4.2 to 18.6 ton ha ${ }^{-1}$ were $^{-}$ observed for different tomato varieties evaluated (Richardson, 2013). In other way, mean marketable fruit yield of 11.61 to 22.95 ton $\mathrm{ha}^{-1}$ was reported by Regassa et al. (2016).

Table 1. Mean number of fruit cluster per plant, mean marketable fruit number per plant, fruit weight per plant and mean marketable fruit yield ton per hectare since 2014 to 2015.

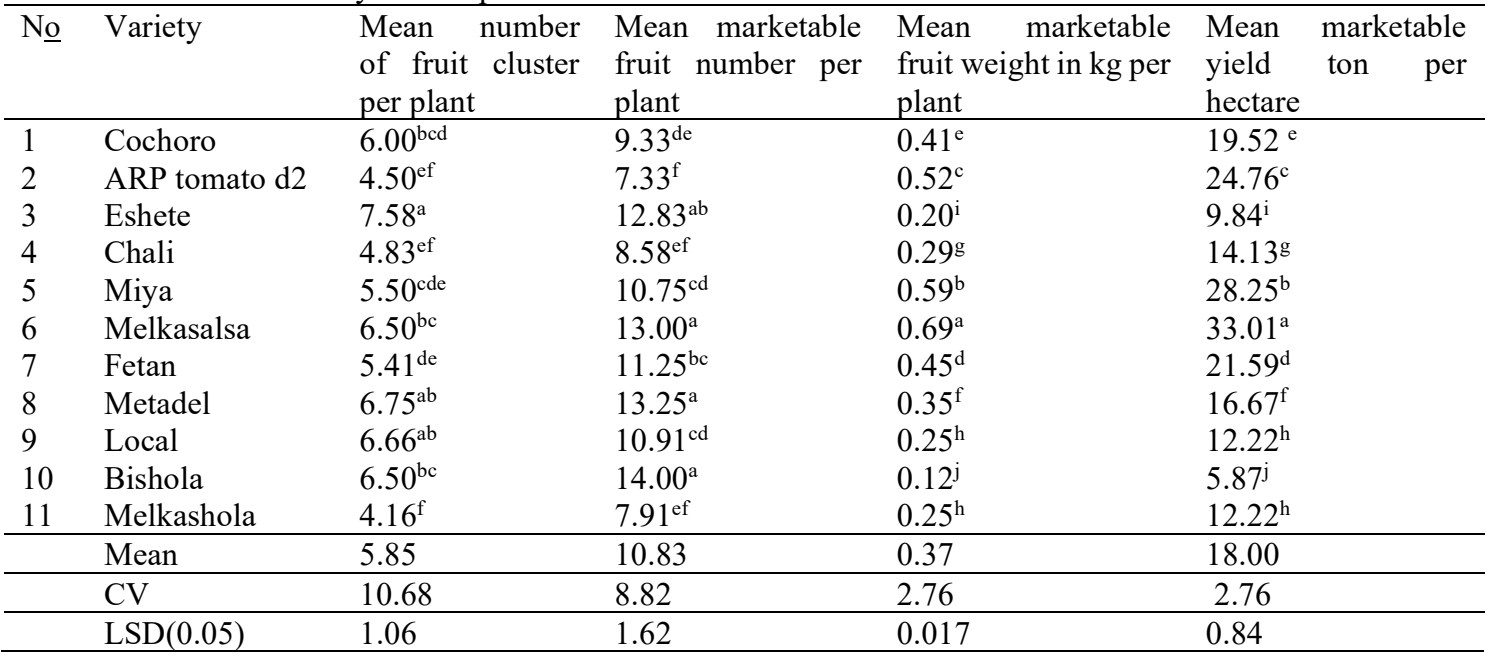

* Means followed by the same letter in same column are not significantly different from each other.

* $C v=$ coefficient of variations.

* LSD $(0.05)=$ Least significant difference at $5 \%$.

The same trials were conducted in the second year. Result revealed that, there was a high significant variation 
among the varieties evaluated $(\mathrm{P} \leq 0.05)$ in mean number of fruit cluster per plant, mean marketable fruit number per plant, marketable fruit weight per plant and mean marketable fruit yield ton per hectare in the second year since 2015 to 2016 in Jimma area (Table 2).

In second year, the variety Melkasalsa resulted in highest significance difference in its mean number of fruit cluster per plant among all tested varities with the score of 23.33. By this result, as compared to its first year result, it was about three fold. The least was recorded in the variety Bishola (6.13) with statistically par with Metadel (7.6), Melkashola (9.06) and Eshete (9.2). These varities were all most same to the first year result when they compered.

Mean of marketable fruit number per plant was resulted in highest significance difference, variety Melkasalsa among tested varities with the score of 54 marketable fruit number per plant. With this result, it was four fold to the first year result which was 13 marketable fruit number per plant. An agreement to this result, the variety "Soraya"" scored the largest number of marketable fruit per plant (Richardson, 2013). In similar manner, variety Martha Washington scored greater marketable fruit number (110,183 fruit/acre) over season tested when compared to any of the heirloom varieties (Shubin et al., 2013). The least was recorded in the variety Bishola (12.06) and Metadel (16.13) and they are almost same when compared to the first year result.

Mean of marketable fruit weight per plant was highly significant difference in variety Melkasalsa $(0.852 \mathrm{~kg})$ and followed by local $(0.749 \mathrm{Kg})$. During the second year, Melkasalsa variety scored $23.47 \%$ mean of marketable fruit weight per plant than the first year evaluation. This was may be due to the optimum temperature range and sufficient rain fall that facilitate the rate of photosynthesis which is linked with production of assimilates and transport from source sinks. An agreement to this result, fruit weights per plant was $2.1 \mathrm{~kg}$ per plant for 'Soraya' which was the highest marketable fruit weights per plant among the varieties evaluated (Richardson, 2013). The least marketable fruit weight per plant was recorded by the variety Bishola $(0.139 \mathrm{Kg})$ and Metadel $(0.182 \mathrm{~kg})$. In consistency with this result, $0.6 \mathrm{~kg}$ per plant for variety 'Yellow Jubilee' was reported as the least result (Richardson, 2013).

Mean of marketable fruit yield in ton per hectare was highly significant difference in variety Melkasalsa $\left(40.547\right.$ ton $\left.\mathrm{ha}^{-1}\right)$ and followed by local $\left(35.657\right.$ ton $^{-1}$ ). It was also about $22.83 \%$ yield advantage than its first year evaluation. This highest marketable fruit yield was due to the integration of highest fruit number, fruit weight and number of fruit cluster recorded on this variety. The genetic make-up of the variety also plays significant role on yield of these varieties. This statement agrees to the association of characters like fruit yield per plant, number of fruits per plant, numbers of fruit clusters per plant and shape index are the most important fruit yield components which contributes more to highest fruit yield per hectare (Chernet and Zibelo, 2014). In line this experiment yield result, the highest marketable yield was obtained by Melkasalsa (Chernet and Zibelo, 2014). In the same manner, Regassa et al. (2016) reported that, marketable fruit yield was positively correlated with fruit number per plant and single fruit weight which indicates that, varieties with higher fruit number per plant and single fruit weight gives high marketable fruit yield. In line with this research result, the variety Martha Washington scored greater marketable yield (44,092 lbs /acre) and Pruden's Purple variety had higher marketable yield (28,024 lbs/acre) than all other heirloom varieties (Shubin et al., 2013). Inversely to Jimma area, the maximum fruit yields per hectare were obtained from Melkashola and Bishola in Erer valley of Babile (Benti et al., 2017). Also Lemma (2002) reported that, a variation in mean marketable fruit yield range between 7.21 to 48.80 ton ha $^{-1}$. Adelana (1978) also reported that, about 20 tons per hectare of tomato yield in temperate region. The least marketable fruit yield ton per hectare was recorded by the variety Bishola $\left(6.6\right.$ ton $\left.^{-1}\right)$ and Metadel $\left(8.66\right.$ ton $\left.\mathrm{ha}^{-1}\right)$. In line to this, the least yield was recorded by Bishola (Chernet and Zibelo, 2014). An agreement with this, the minimum yield was obtained from Chali, Fetan and 'Babile local in Erer valley of Babile (Benti et al., 2017). In the same way, tomato variety DT97/215A gave the least values (Olaniyi et al., 2010).

In other way temperature has a pronounced effect in the flowering of tomato plants. The highest maximum temperature observed since $2^{\text {nd }}$ year experiment was in the month of February $\left(27.5^{\circ} \mathrm{c}\right)$ which is the optimum temperature for flower production. These flowers production resulted in highest fruit set which resulted in highest marketable yield mainly in Melkasalsa variety which produced the highest fruit cluster per plant, marketable fruit number per plant and marketable fruit weight per plant. This temperature also the optimum temperature which facilitate the rate photosynthesis and the assimilates from sources to sinks in the tomato plant. An agreement to this, Adams et al.(2001) reported that, Temperature significantly affects the partitioning of assimilates between the vegetative and generative parts. The average maximum monthly temperature observed since $2^{\text {nd }}$ year trials was $23.97^{\circ} \mathrm{c}$. In line with Araki et al. (2000) reported that, the optimum temperature for tomato production is 21 ${ }^{\circ} \mathrm{C}$ to $25^{\circ} \mathrm{C}$ with an average monthly minimum temperature $>18^{\circ} \mathrm{C}$ and a monthly maximum temperature of $27^{\circ} \mathrm{C}$. Effects of temperature were more pronounced at flowering stage compared to pre-flowering stage. In line to this, Islam (2011) stated that, photosynthetic rate, number of fruits, individual fruit weight and fruit yield/plant significantly decreased with the temperature $\left(32^{\circ} \mathrm{C}\right)$ at pre-flowering and flowering stages.

Throughout the five months of $2^{\text {nd }}$ year cropping season trials, $336.50 \mathrm{~mm}$ of total and $67.3 \mathrm{~mm}$ average monthly rain fall was recorded(Fig 3). This amount of rain fall is important for efficient moisture supply and for 
the reduction of some insect pest which may affect the fruit yields of tomato. The obsereved average monthly RH of $65.92 \%$ optimal which hinder the occurrences of fungal pathogens that may affects the marketable fruit yield of tomato (Fig 3).

Table 2. Mean number of fruit cluster per plant, mean marketable fruit number per plant, fruit weight per plant and mean marketable fruit yield ton per hectare since 2015 to 2016.

\begin{tabular}{llllll}
\hline No & Variety & $\begin{array}{l}\text { No of fruit cluster } \\
\text { per plant }\end{array}$ & $\begin{array}{l}\text { No of fruit } \\
\text { per plant }\end{array}$ & $\begin{array}{l}\text { Fruit weight in Kg } \\
\text { per plant }\end{array}$ & $\begin{array}{l}\text { Tomato Yield ton } \\
\text { per hectare }\end{array}$ \\
\hline 1 & Chali & $11.333^{\text {cd }}$ & $26.133^{\text {cde }}$ & $0.375^{\text {ef }}$ & $17.857^{\text {ef }}$ \\
2 & Eshete & $9.200^{\text {def }}$ & $25.333^{\text {de }}$ & $0.448^{\text {de }}$ & $21.32^{\text {de }}$ \\
3 & Melkasalsa & $23.333^{\mathrm{a}}$ & $54.200^{\mathrm{a}}$ & $0.852^{\mathrm{a}}$ & $40.547^{\mathrm{a}}$ \\
4 & Melkashola & $9.067^{\text {def }}$ & $28.267^{\text {cd }}$ & $0.148^{\mathrm{g}}$ & $7.047^{\mathrm{g}}$ \\
5 & Miya & $10.000^{\text {cde }}$ & $28.333^{\text {cd }}$ & $0.345^{\mathrm{f}}$ & $16.453^{\mathrm{f}}$ \\
6 & Bishola & $6.133^{\mathrm{f}}$ & $12.060^{\mathrm{f}}$ & $0.139^{\mathrm{g}}$ & $6.600^{\mathrm{g}}$ \\
7 & Fetan & $11.200^{\text {cd }}$ & $23.000^{\mathrm{e}}$ & $0.488^{\mathrm{d}}$ & $23.230^{\mathrm{d}}$ \\
8 & Metadel & $7.600^{\mathrm{ef}}$ & $16.133^{\mathrm{f}}$ & $0.182^{\mathrm{g}}$ & $8.660^{\mathrm{g}}$ \\
9 & ARP tomato d2 & $10.733^{\text {cde }}$ & $25.467^{\mathrm{de}}$ & $0.461^{\mathrm{de}}$ & $21.933^{\mathrm{de}}$ \\
10 & Cochoro & $12.533^{\mathrm{c}}$ & $30.133^{\mathrm{c}}$ & $0.600^{\mathrm{c}}$ & $28.587^{\mathrm{c}}$ \\
11 & Local & $18.067^{\mathrm{b}}$ & $46.867^{\mathrm{b}}$ & $0.749^{\mathrm{b}}$ & $35.657^{\mathrm{b}}$ \\
\hline & Mean & 11.745 & 28.721 & 0.435 & 20.717 \\
\hline & CV & 15.774 & 9.345 & 12.942 & 12.939 \\
\hline & LSD(0.05) & 3.155 & 4.576 & 0.096 & 4.5656
\end{tabular}

* Means followed by the same letter in same column are not significantly different from each other.

* $C v=$ coefficient of variations.

* LSD $(0.05)=$ Least significant difference at $5 \%$.

Mean of marketable fruit yield in ton per hectare Over two years revealed that, there was a high significant variation among the varieties evaluated $(\mathrm{P} \leq 0.05)$ (Table 3$)$. Mean of marketable fruit yield in ton per hectare over two years was highly significant difference in variety Melkasalsa (36.78 ton ha $\left.{ }^{-1}\right)$ and followed by Cochoro, Local, ARPTd2 tomato, Miya and Fetan with yield of 24.05,23.94, 23.34,22.35 and 22.41 ton $^{-1}$ respectively. Even $^{-1}$ though the local variety yield was statistically par with latter varieties (follower of Melkasalsa), it has unattractive color, less tasty and contain more amount of seeds rather than fleshy which makes unique. The highest marketable fruit yield in ton per hectare was due to the integration of highest fruit number, fruit weight and number of fruit cluster recorded on each plant variety. The genetic make-up of these varieties also plays significant role on yield of the varieties. In line with this, Regassa et al.(2016) reported that, there was a variation among the varieties. Varietal difference was obvious that, the variety UC82B produce more total fruit yield ha ${ }^{-1}$ than Roma VF where it had 10.6\% higher on the average (Isah et al., 2014). In same way, Olaniyi et al. (2010) reported that, the highest fruit yield values were recorded from UC82B wand closely followed by Ibadan and Ogbomoso Local with better growth, marketable and good quality fruit yield performance under hazardous climatic condition Oyo sate of Nigeria. In similar way, Variety Miya gave higher marketable fruit yield and higher average of single marketable fruit weight than other varieties in Borena areas (Regassa et al., 2016).

The least marketable fruit yield ton per hectare was recorded by the variety Bishola $\left(6.233\right.$ ton ha $\left.\mathrm{h}^{-1}\right)$ and followed by Melkashola (9.63 ton $\left.\mathrm{ha}^{-1}\right)$. In line with this result, the least mean marketable fruit yield was obtained from the variety Fetan in Borena areas (Regassa et al., 2016). In similar manner, the maximum fruit yield per hectare were obtained from Melkashola, Bishola while the minimum were from Chali, Fetan and 'Babile local (Benti et al., 2017).

The varietal differences in growth and yield might be attributed to the differences in ecological distribution of the tomato varieties. An agreement to this, the hybrid tomato varieties are more suitable to Debreziet and Koka area which is relatively low temperature and high altitude areas(Binalfew et al., 2016). The low response of tomato at Melkassa might be due to high temperature of the area and low fertility of the soil (Binalfew et al., 2016). Besides the differences of ecology, due to the genetic make-up; the low marketable yield obtained for some tomato varieties used might be due to none development of flowers into fruits as about $50 \%$ of the flowers developed into fruits. In line to this, Adelana (1975) reported that, only 50\% of the flowers developed into fruits. As a result of ecological conditions the fruit yield of tomato may be affected. An agreement to this, poor fruit set in tomato may be as a result of high temperatures that are not conducive for good fruit set (Simon and Sobulo, 1974; Olaniyi, 2007). 
Table 3. Mean of marketable fruit yield ton per hectare over two (2) years (2014 to 2016).

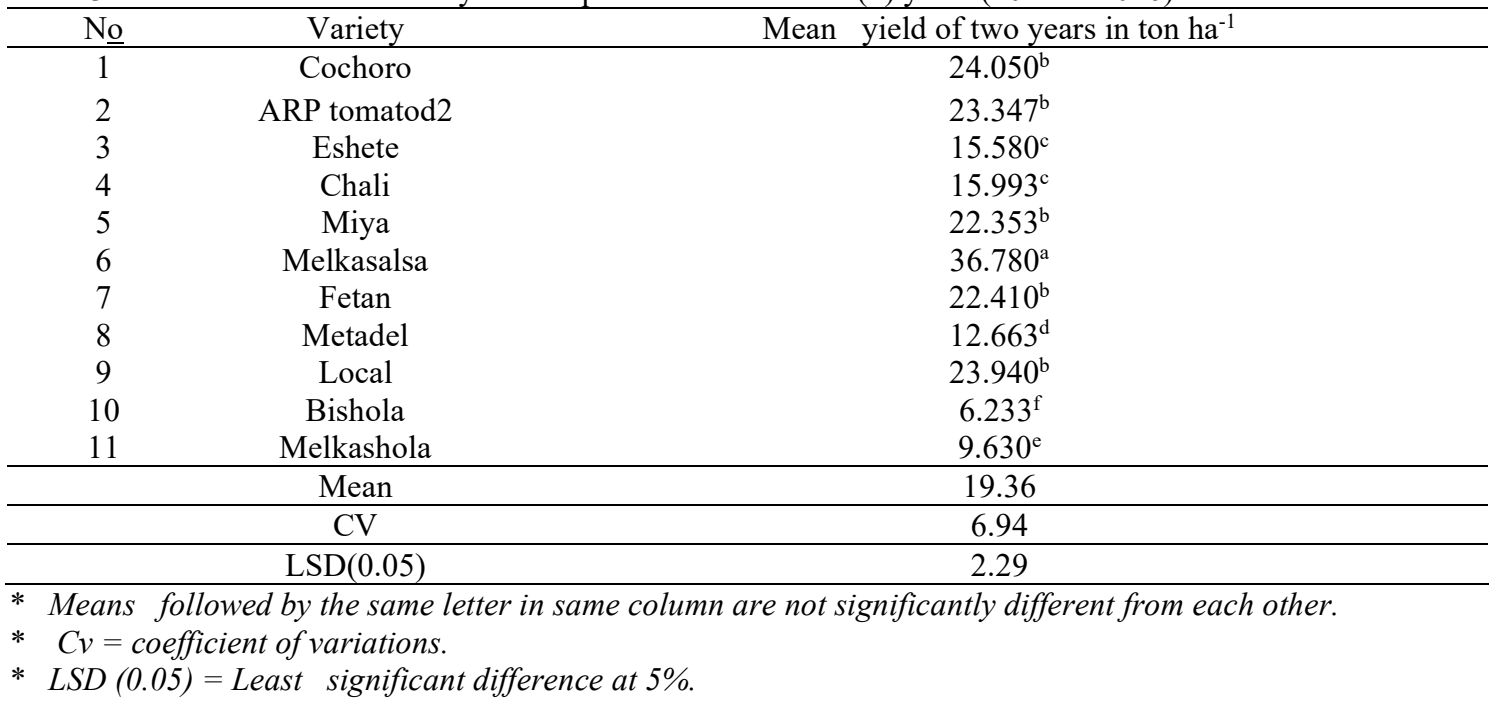

\section{Summary and conclusions}

Tomato (Lycopersicon esculentum Mill.) is one of the most widely grown vegetable crops in the world. In Ethiopia, tomato ranks fourth in total production after Ethiopian cabbage, red pepper and green pepper from cultivated vegetable crops. The crop has high economic importance in Ethiopia. It is consumed in every household in different styles, but in certain areas. Its area of production and yield were increased which is about $90.05 \%$ and $92.69 \%$ respectively. Several tomato varieties had been released by the Melkassa Agricultural Research Center for commercial production and small scale farming systems in Ethiopia.

For adaptation, an experiment was conducted for two consecutive years 2014/15 and 2015/16 in jimma area using ten improved and one farmer's local tomato varities in randomized complete block design (RCBD) with three replications. Result of $1^{\text {st }}$ year trial revealed that, there were high significant variations in mean of variables among the varities. Mean of marketable fruit yield in ton per hectare was highly significant difference in variety Melkasalsa (33.01 ton $\mathrm{ha}^{-1}$ ) and followed by Miya (28.25 ton $\mathrm{ha}^{-1}$ ). The same trial was conducted in the $2^{\text {nd }}$ year. Result revealed that, there were also a high significant variations among the varieties evaluated in mean of variables recorded. Accordingly Melkasalsa resulted in highest significance difference in its mean of marketable fruit yield in ton per hectare (40.547 ton $\mathrm{ha}^{-1}$ ) and followed by local (35.657 ton ha-1). It was also about $22.83 \%$ yield advantage than its first year evaluation. Mean of marketable fruit yield over two years revealed that, there was a high significant variation among the varieties evaluated. Accordingly, mean of marketable fruit yield in ton per hectare over two years was highly significant difference in variety Melkasalsa (36.78 ton ha ${ }^{-1}$ ) and followed by Cochoro (24.05 ton $\left.\mathrm{ha}^{-1}\right)$. The least was recorded by the variety Bishola ( 6.6 ton $\mathrm{ha}^{-1}$ ) and Metadel ( 8.66 ton ha$\left.{ }^{1}\right)$. The highest marketable fruit yield was due to the integration of highest fruit number, fruit weight and number of fruit cluster recorded on this variety. The genetic make-up of the variety also plays significant role on yield of these varieties. In other way temperature has a pronounced effect in the flowering of tomato plants. The highest maximum temperature observed since $2^{\text {nd }}$ year $\left(27.5^{\circ} \mathrm{c}\right)$ which is the optimum temperature for flower production which resulted in highest yield. Over all Melkasalsa and Cochoro were recommended as $1^{\text {st }}$ and $2^{\text {nd }}$ respectively in jimma area and similar conditions due to qualified in all evaluated variables

Abbreviations used

JARC Jimma Agricultural research center

FAO Food and Agricultural Organization

CSA Central Statics Authority

\section{Acknowledgements}

I feel great pleasure to place on record my deep sense of appreciation and heartfelt thanks to my staff members' from initial stage of trials to completion of the write-up of the this article. I express my sincere thanks to all Horticultural crops process team MARC for their assistance in providing seed source and team work. I would like to extend my sincere gratitude to EIAR for providing us with financial support of the experiment. Finally, Thanks to God for every events in my life!

\section{Reference}

Abdelmageed, A.H., Gruda, N. and Geyer, B., 2003, October. Effect of high temperature and heat shock on tomato 
(Lycopersicon esculentum Mill.) genotypes under controlled conditions. In Conference on International Agricultural Research for Development,Vol. 34,(10), pp: 1064-1076.

Adams, S.R., Cockshull, K.E. and Cave, C.R.J., 2001. Effect of temperature on the growth and development of tomato fruits. Annals of Botany, 88(5), pp: 869-877.

Adelana, B.O.,1978. Effect of flower removal on the tomato. India J.Hortic., Vol. 35(1), pp: 28-34.

Agrisnet, 2010. Tomato. Department of Agriculture, Sikkim, India.

Gemechis, A.O., Struik, P.C. and Emana, B., 2012. Tomato production in Ethiopia: constraints and opportunities. Tropentag 2012, International Research on Food Security, Natural Resource Management and Rural Development. Resilience of Agricultural Systems against Crises: Book of Abstracts, p.373.

Araki, T., Kitano, M. and Eguchi, H.,2000. "Dynamics of fruit growth and photoassimilate translocation in tomato plant (Lycopersicon esculentum. Mill.) under controlled environment." In International Conference and British-Israeli Workshop on Greenhouse Techniques towards the $3^{\text {rd }}$ Millennium 534, pp. 85-92.

Baloch,F.A.,1994.Vegetable crops. In: Horticulture National Book Foundation, Islamabad.pp: 500-508.

Benti,G., Degefa, G., Biri, A. and Tadesse, F., 2017. Performance Evaluation of Tomato (Lycopersicon esculentum Mill.) Varieties Under Supplemental Irrigation at Erer Valley, Babile District, Ethiopia. Journal of Plant Sciences, Vol. 5(1):1-5.

Beyene, T.M., 2013. Morpho-agronomical characterization of taro(Colocasia esculenta) accessions in Ethiopia. Plant science publishing group, 1(1):1-9.

Binalfew,T ., Alemu,Y., Geleto,J., Wendimu,G. and Hinsermu,M.,2016. Performance of Introduced Hybrid Tomato (Solanum lycopersicum Mill.) Cultivars in the Rift Valley, Ethiopia. Int. J. of Research in Agriculture and Forestry, Vol.3 (10):25-28.

Birhanu, K. and Tilahun, K., 2010. Fruit yield and quality of drip-irrigated tomato under deficit irrigation. African J. Food, Agr, Nut and Development, Vol.10(2):2139-2151.

Chernet, S. and Zibelo, H., 2014. Evaluation of tomato varieties for fruit yield and yield components in western lowland of Tigray, Northern Ethiopia. Int. J. Agric. Res.,Vol. 9, pp.259-264, ISSN 1816-4897 l DOI: 10.39231

Choudhury. B., 1979. Vegetables $6^{\text {th }}$ Revised Edn. The Director, National Book Trust, New Delhi, India, 46p.

CSA , 2012. Report of Federal democratic Republic of Ethiopia, Statistical Report on Socio Economic Characteristics of the Population in Agricultural Households, Land Use, Area and Production of Crops. Addis Ababa, Ethiopia.

CSA, 2015. The Federal Democratic Republic of Ethiopia, Central Statistical Agency, Agricultural Sample Survey, 2015, Volume I, Report on Area and Production of Crops, (Private Peasant Holdings, Meher Season), Addis Ababa, Ethiopia.

CSA, 2016. The Federal Democratic Republic of Ethiopia, Central Statistical Agency, Agricultural Sample Survey, 2016, Volume I, Report on Area and Production of Crops, (Private Peasant Holdings, Meher Season), Addis Ababa, Ethiopia.

FAO, 2005. FAOSTAT, Available at http://faostat.fao.org.

FAO, 2006. FAO Production Year Book. Basic Data Unit, Statistics Division, FAO, Rome, Italy, No. 55, pp :125127.

FAO, 2009. Statistical Bulletin, Rome, No. 150, pp 1-2.

FAOSTAT, 2012. Statistical database of the food and agriculture organization of the United Nations.Food and Agriculture Organization (FAO),Rome,Italy. http://faostat.fao.org/.

Isah, A.S., Amans, E.B., Odion, E.C. and Yusuf, A.A.,2014.Growth Rate and Yield of Two Tomato Varieties (Lycopersicon esculentum Mill) under Green Manure and NPK Fertilizer Rate Samaru Northern Guinea Savanna. International Journal of Agronomy, $\quad$ ID 932759, http://dx.doi.org/10.1155/2014/932759.

Islam,M.T., 2011. Effect of temperature on photosynthesis, yield attributes and yield of tomato genotypes. Int. J. Expt. Agric. 2(1):8-11

JARC AMG, 2018.Jimma agricultural research center agro metrological and geo-special data record.

Jindal, S.K., Dhaliwal, M.S. and Chawla, N., 2015. Comparative performance of different tomato hybrids under naturally ventilated polyhouse.Int. Jour. of Hort.iculture, Vol.5(14), Pp :1-12

Lemma, D .2002. Research experience and production prospects. Ethiopian Agricultural Research Organization (EARO), Addis Ababa, Ethiopia, pp: 20-28.

Maerere, A.P., Sibuga, K.P., Mwajombe, K.K., Kovach, J. and Erbaugh, M., 2006. Baseline survey report of tomato production in Mvomero district-Morogoro region, Tanzania. Sokoine University of Agriculture Faculty of Agriculture, Morogoro, pp.1-31.

MARD, 2016. Plant and Animal Quarantine Regulatory, Ethiopian Ministry of Agriculture. Variety Release Booklet.,Addis Ababa, Ethiopia

Olaniyi, J. O., Akanbi, W.B., Adejumo, T. A. and Akande O. G., 2010. Growth, fruit yield and nutritional quality of tomato varieties, Afr. Jour. F. Sc., Vol. 4(6):398 - 402, 
Olaniyi,J.O., 2007.Evaluation of Yield and Quality Performance of Grain Amaranth Varieties in the South western Nigeria. Res. J. Agron.,Vol. 1(2): 42-45.

Regassa, D., Tigre, W. and Shiferaw, A., 2016. Tomato (Lycopersicon esculentum Mill.) varieties evaluation in Borana zone, Yabello district, southern Ethiopia. Journal of Plant Breeding and Crop Science, Vol. 8(10):206-210.

Richardson,K.V.A.,2013.Evaluation of five staked tomato(Lycopersiconesculentum.mill.) Varieties for quality and yield. Gladstone road agricultural center crop research report no. 16

Shubin, K. S., Dan, E., Maria, R., Valerie, C., Scott, M., Hans, S., Larry, S. and Dennis, N., 2013.Evaluation of Organic Heirloom Tomato Varieties. Midwest Vegetable Trial Report.

Simon J.H., Sobulo, R.A., 1974. Methods for higher tomato yield in Western State of Nigerian. Paper presented at Institute of Agric. research Conference. Ibadan, Nigeria.

Tewodros, M. and Asfaw, K., 2013. Promotion and evaluation of improved technologies through participatory approach in South Ethiopia: Experience from hot pepper. Unique Research Journal of Agricultural Sciences, Vol.1(4):057-062.

Wikipedia, 2016. The free encyclopedia, Available at http://en.wikipedia.org, accessed on 8 julay, 2019.

Yeshiwas, Y., Belew, D. and Tolessa, K., 2016. Tomato (Solanum lycopersicum L.) Yield and fruit quality attributes as affected by varieties and growth conditions. World J Agric Sci., 12(6):404-408. 